\title{
Toxicity of Saffron Extracts on Cancer and Normal Cells: A Review Article
}

\author{
Masihollah Shakeri ${ }^{1}$, Akbar Hashemi Tayer ${ }^{1}$, Heshmatollah Shakeri ${ }^{1}$, Abdolreza \\ Sotoodeh Jahromi ${ }^{1 *}$, Malihe Moradzadeh², Mohammad Hojjat-Farsangi ${ }^{3}$
}

\begin{abstract}
Background and Aim: Medicinal plants have played an important role in human health since the Stone Age. According to $\mathrm{WHO}, 80 \%$ of Asian and African people rely on traditional medicine and medicinal plants to conserve their health. Saffron has received much attention among the herbal compounds related to cancer treatment. Methods: This review aims to provide an overview of in-vitro and in-vivo evaluation molecule mechanism for anti-tumor activity, cancer preventing and protective effects of saffron extract. The review is based on the available data accessible in PubMed, Science Direct, Google Scholar, Magiran.ir, and SID.ir databases. Results: Saffron has selective toxic and preventive effects on cancerous cells and without adverse effects on normal cells and prevents tumor formation. Saffron appears to reduce the toxic effects of anticancer drugs. Saffron has toxicity effects when used in high amounts, which are far greater than those are used in human food culture. Conclusions: Considering the observed effects of saffron on the removal of cancer cells, saffron extract can be used in the treatment and prevention of cancer after confirmation in human clinical trials. According to the high $\mathrm{IC}_{50}$ of saffron extracts in normal cells, its toxicity against non-cancerous cells is low and its use is safe. Besides, the studies suggested the cytotoxic effects of saffron on some of the more cancers, including nervous system cancer and common cancers. Further studies are required to determine the effective dose and influence of mechanism of saffron in various animal type of cancers.
\end{abstract}

Keywords: Cancer- cytotoxicity- Saffron extract

Asian Pac J Cancer Prev, 21 (7), 1867-1875

\section{Introduction}

Malignancy is the second cause of death and one of the worldwide major public health with a significant incidence and mortality rates in the developing and developed countries (Madani et al., 2010b; Gezici and Şekeroğlu, 2019).

About 18.1 million new cancer cases and 9.6 million cancer deaths happened worldwide in 2018 (Ferlay et al., 2019). Some types of cancers are preventable by making appropriate changes in the lifestyle, diet and physical activities (Madani et al., 2010a; Heitz et al., 2018).

Among the various categories of cancer treatment including surgery, radiotherapy, hormone therapy, chemotherapy, targeted therapy, and herbal therapy, phytotherapy has been developed a tremendously important strategy for cancer management in recent years, due to its advantages for the treatment and prevention (Sanaei et al., 2018; Gezici, 2019; Sanaei et al., 2020). Medicinal plants have played an important role in human health since the Stone Age (Halberstein, 2005). According to $\mathrm{WHO}, 80 \%$ of Asian and African people rely on traditional medicine and medicinal plants to conserve their health (Organization, 1978).

Due to the adverse effects of conventional cancer treatment drugs (Kokhaei et al., 2016; Nurgali et al., 2018; Hain et al., 2019) and drug resistance (Khamisipour et al., 2016), the prevention or treatment of cancer with herbal compounds has recently been considered by many researchers (Qi et al., 2015; Sanaei et al., 2017a; Sanaei et al., 2017b; Lou et al., 2018; Hain et al., 2019) among which saffron has been received much attention (Bhandari, 2015; Gudarzi et al., 2015).

Originally, the word saffron originates from the French word Safran which comes from the Latin word Safranum. The saffron plant is a part of the Iridaceae family, which is an ancient spice and a natural food dye that has been used for the treatment of various illnesses in the long human history (Small, 2016; Khanali et al., 2017). This spice possesses numerous beneficial properties and traditionally

${ }^{1}$ Research Center for Non-Communicable Disease, Jahrom University of Medical Sciences, Jahrom, Iran. ${ }^{2}$ Golestan Rheumatology Research Center, Golestan University of Medical Sciences, Gorgan, Iran. ${ }^{3}$ Department of Oncology-Pathology, Immune and Gene Therapy Lab, Cancer Center Karolinska (CCK), Karolinska University Hospital Solna and Karolinska Institute, Stockholm, Sweden.*For Correspondence: sotoodehj2002@yahoo.com 
it has been used as an anti-asthmatic, antidepressant, anti-blood pressure, antioxidant, anti-inflammatory, anticonvulsant, and as an antitussive. Saffron has recently been received attention for its anticancer properties (Hoshyar and Mollaei, 2017).

Three-hundreds tons of saffron is produced annually in the world, 90\% of which is produced in Iran (Khanali et al., 2017). The most important part of saffron for nutritional or therapeutic purposes is its stigma. The therapeutic properties of saffron stigma are due to the presence of three major secondary metabolites. They include: (i) Crocin (mono-glucosyl or di-glucosyl poly N-esters) and water-soluble derivatives that create the red colour of saffron; (ii) Picrocrocin (the glucoside precursor of safranal, responsible for the bitter taste of saffron); and (iii) Safranal (dicarboxylic acid precursor of crocin) that produces the scent of saffron (Hosseinzadeh et al., 2009; Hosseinzadeh et al., 2012). Low levels of thiamine and riboflavin are also present in saffron (Alonso et al., 2001; Azarabadi and Özdemir, 2018). Most of the beneficial and therapeutic properties of saffron are related to the antioxidant and anti-inflammatory effects of saffron extract and its active components (Lecomte et al., 2017; Hosseini et al., 2018; Zeinali et al., 2019).

There are considerable studies that focused on extraction of saffron and its active constituents to prevent and treat cancer, but the exact mechanism of these effects has not been discovered. An herbal compound is used as a prophylactic or therapeutic agent for a disease, that has slight or no toxicity and has high efficiency, edibility, a well-known mechanism of action, and low price (Abdullaev, 2002; Lecomte et al., 2017; Mani and Natesan, 2018).

This review aims to provide a brief overview of invitro and in-vivo evaluation of molecular mechanisms for anti-tumor activity, cancer-preventing and protective effects, and toxicity of saffron based on the available reports in the literature.

\section{Materials and Methods}

\section{Methods}

In this study, a search was conducted to investigate relevant studies in PubMed, Science Direct, Google scholar, Magiran.ir, and SID.ir databases.

Keywords searched in the databases were extracted from MESH in the PubMed database including Saffron, Neoplasm, Cancer, Toxicity, Cytotoxicity effect, Tumoricidal effect, Protective effect, and Tumor.

The research included in which total saffron extracts (not one of the specific saffron ingredients) were interventional studies on humans and animals (in-vivo) as well as laboratory studies on cancer cells (in-vitro) for the period between 1975-2020. However, no study was found which focus on human.

The articles in which saffron was studied in a mixture with other herbs, specific saffron ingredient, and or the studied saffron belonged to a particular strain were excluded.

\section{Results}

The results of the investigation of experimentally cell culture (in-vitro) and animal (in-vivo) studies in the literature on saffron extracts were included. However, no in-vivo human study was found.

\section{Anti-cancer effect of saffron \\ In-vitro anti-cancer effect of saffron}

The effect of ethanolic extract of saffron on lung tumor cells and normal lung fibroblasts showed that tumor cells were more sensitive than normal cells to the inhibitory effect of the saffron extract on DNA and RNA synthesis (Abdullaev and Frenkel, 1992). Also, saffron may directly target DNA sequences and modulate transcription (Bathaie et al., 2007).

Saffron extract at concentrations of 20, 40 and $100 \mu \mathrm{g} / \mathrm{ml}$ applied for 24,48 and 72 hours reduced the expression self-renewal genes such as OCT4, KLF, SOX2, NANOG, and nucleostemin in gastric adenocarcinoma tumor cell line (Akbarpoor et al., 2020).

The effect of ethanolic extract of saffron at concentrations of $200-2000 \mu \mathrm{g} / \mathrm{ml}$ on HeLa cell line and Hep G2 cell line showed that $\mathrm{IC}_{50}$ on these two cell lines were 800 and $950 \mu \mathrm{g} / \mathrm{ml}$ after 48 hours, respectively. Apoptotic and non-apoptotic functions played a role in this toxicity. In that study, Reactive Oxygen Species (ROS) has no role in these effects and significant inhibition of DNA and RNA synthesis (50\%) was observed at 100-150 $\mu \mathrm{g}$ / $\mathrm{ml}$ concentrations but no protein synthesis inhibition was observed even at high concentrations (Tavakkol-Afshari et al., 2008).

The anti-cancer effects of saffron can be partially chain reaction, interference of carotenoids with topoisomerase (Abdullaev, 2002; Lee and Park, 2003; Patel et al., 2017), cell proliferation inhibition, apoptosis induction (Samarghandian et al., 2013; Patel et al., 2017; Colapietro et al., 2019b), inhibition of cell cycle progression and cell growth (D'Alessandro et al., 2013; Colapietro et al., 2019b; Gezici, 2019), activating an intrinsic apoptotic (caspase) pathway (Amin et al., 2011; D'Alessandro et al., 2013; Samarghandian et al., 2013), lactate dehydrogenase activity (LDH), antioxidant activity, DNA fragmentation (Gezici, 2019), cell differentiation enhancement, tumor metabolism modulation, stimulation of cell-to-cell communication and immune modulation (Colapietro et al., 2019b), radical scavenging (Wang and DU, 2018), arresting cell cycle progression, and matrix metalloproteinase expression suppression (Khorasanchi et al., 2018).

Ethanolic extract of saffron had a selective cytotoxic effect on epithelial cells like hepatocellular carcinoma and HeLa cell line, while it had no toxicity on normal fibroblast cells in rats (Tavakkol-Afshari et al., 2008). Saffron extract inhibits the cell viability and cell growth of cancerous cells in a time and concentration-dependent manner (Gezici, 2019).

Different concentrations of saffron extract; i.e. $100,200,400$, and $800 \mu \mathrm{g} / \mathrm{ml}$ for three days on adeno-carcinomic human alveolar cells (A549) increased apoptosis in a dose-dependent manner (Samarghandian 
Table 1. Anti-Cancer Effect of Saffron from in-vitro Studies

\begin{tabular}{|c|c|c|}
\hline Research & Target cell & Results \\
\hline $\begin{array}{l}\text { (Abdullaev and Frenkel, } \\
\text { 1992) }\end{array}$ & $\begin{array}{l}\text { A549 cells (derived from a lung tumor), WI-38 cells } \\
\text { (normal lung fibroblasts) and VA-13 cells (WI- } 38 \\
\text { cells transformed in vitro by SV40 tumor virus) }\end{array}$ & $\begin{array}{l}\text { Inhibited selectively DNA and RNA } \\
\text { synthesis in malignant cells }\end{array}$ \\
\hline (Abdullaev et al., 2003) & $\begin{array}{l}\text { Malignant cells (HeLa, A-204 and HepG2) and } \\
\text { normal human cells }\end{array}$ & $\begin{array}{l}\text { Inhibited selectively proliferation in } \\
\text { human malignant cells. }\end{array}$ \\
\hline (Chryssanthi et al., 2007) & MCF-7 and MDA-MB-231 breast cancer cells & Inhibited cancer cell Proliferation \\
\hline $\begin{array}{l}\text { (Tavakkol-Afshari et al., } \\
\text { 2008) }\end{array}$ & $\begin{array}{l}\text { Cervical carcinoma (HeLa cells), Hepatocellular } \\
\text { carcinoma (Hep G2), non-malignant cells (L929) }\end{array}$ & $\begin{array}{l}\text { Induced selectively cell death in } \\
\text { malignant cells }\end{array}$ \\
\hline (Mousavi et al., 2009) & Breast cancer (MCF-7) cells & Induced proapoptotic effects \\
\hline (Amin et al., 2011) & HepG2 cells & $\begin{array}{l}\text { Inhibited nuclear factor-kappa B } \\
\text { activation, increased cleavage of } \\
\text { caspase-3, DNA damage, and cell cycle } \\
\text { arrest }\end{array}$ \\
\hline (Samarghandian et al., 2013) & Pulmonary Tumor cells (A549) & $\begin{array}{l}\text { Induced apoptosis by activation of } \\
\text { caspase pathways }\end{array}$ \\
\hline (D’Alessandro et al., 2013) & Human Prostate Cancer (BPH-1 cell line) & $\begin{array}{l}\text { Inhibited cell proliferation, progression, } \\
\text { induced cell cycle arrest and apoptosis } \\
\text { by caspase-dependent pathway }\end{array}$ \\
\hline (Festuccia et al., 2014) & Prostate Cancer Cells (PC3 and 22rv1) & $\begin{array}{l}\text { Modulated Metalloproteinases and } \\
\text { Urokinase Expression/Activity }\end{array}$ \\
\hline (Khavari et al., 2015) & Papilloma virus induced malignant TC- 1 cells & Induced apoptosis \\
\hline (Gezici, 2019) & A549, MCF-7 and HeLa human cancer cells & $\begin{array}{l}\text { Induced DNA fragmentation, } \\
\text { cytotoxicity, } \\
\text { cell death, inhibited cancer cell growth }\end{array}$ \\
\hline (Akbarpoor et al., 2020) & Adenocarcinoma tumor cell line (AGS) & $\begin{array}{l}\text { Reduced the expression of OCT4, KLF, } \\
\text { SOX2, NANOG, and Nucleostemin } \\
\text { genes }\end{array}$ \\
\hline
\end{tabular}

et al., 2013).

Saffron causes nonspecific T-cell proliferation in the presence of phytohemagglutinin, indicating that anti-tumor activity of saffron may also be facilitated immunologically (Nair et al., 1995). The saffron extract reduced cell growth in human acute lymphoblastic T-cell leukaemia (Jurkat cell line) (Makhlouf et al., 2016). Table 1 shows the results of in-vitro studies of the anti-cancer effect of saffron.

\section{In-vivo anti-cancer effect of saffron}

Despite the following studies indicating the beneficial anti-cancer effects of saffron, it is worth noting that most in-vivo studies have focused on the components of saffron and little attention has been paid on the saffron itself (Liu, 2004).

The chemoprotective effects of a saffron extract are related to its regulatory effect on lipid peroxidation, antioxidant activity and detoxification (Premkumar et al., 2003).

Oral intake of $100 \mathrm{mg} / \mathrm{kg}$ body weight (bw) of saffron extract up to 12 weeks delayed the emergence and progression of skin tumors due to papillomavirus in the rat. Also, the same treatment with saffron extract restricted the tumor formation in soft tissue sarcoma induced in the rat (Salomi et al., 1991). Oral treatment with methanolic extracts of saffron at a dose of $200 \mathrm{mg} / \mathrm{kg}$ bw increased the lifespan of albino rats with transplanted sarcoma cells (Nair et al., 1991a).

Oral treatment of saffron extracts in rats increased $\beta$-carotene and vitamin-A serum levels (El Daly, 1998) and based on the anti-cancer property of $\beta$-carotene, the anti-cancer effect of saffron may depended on this function (Tarantilis et al., 1994). Encapsulation of saffron extract with liposomes improved its anti-cancer effects in oral administration than intravenous administration (Nair et al., 1992). Administration of the aqueous extract of saffron at concentrations of $100,150,175 \mathrm{mg} / \mathrm{kg}$ bw after 50 days, dose-dependently inhibited gastric adenoma progression in rats (Bathaie et al., 2013). Table 2 summarises the results of in-vivo studies of the anti-cancer effect of saffron. 
Table 2. Anti-Cancer Effect of Saffron from in-vivo Studies

\begin{tabular}{|c|c|c|c|}
\hline Research & Animal/ Dose/ Time & Tumor/Cancer type & Results \\
\hline $\begin{array}{l}\text { (Salomi et al., } \\
\text { 1991) }\end{array}$ & Mouse/ $100 \mathrm{mg} / \mathrm{kg} \mathrm{bw/} 12$ weeks & Papilloma tumor & Restricted tumor incidence to $10 \%$ \\
\hline $\begin{array}{l}\text { (Salomi et al., } \\
\text { 1991) }\end{array}$ & Mouse/ $100 \mathrm{mg} / \mathrm{kg}$ bw/ 12 weeks & Soft tissue sarcoma & Restricted the tumor formation \\
\hline (Nair et al., 1991a) & Albino rats/ 200 mg/kg bw/ 12 weeks & Transplanted sarcoma cells & Increased the lifespan \\
\hline (Das et al., 2010) & $\begin{array}{l}\text { Swiss albino mice/ } 200 \mathrm{mg} \text { saffron } \\
\text { per kg bw/ day/mouse for 6-12 weeks }\end{array}$ & $\begin{array}{l}\text { DMBA-induced skin } \\
\text { carcinoma }\end{array}$ & $\begin{array}{l}\text { prevented or delayed angiogenesis } \\
\text { and tumor progression }\end{array}$ \\
\hline $\begin{array}{l}\text { (Bathaie et al., } \\
\text { 2013) }\end{array}$ & $\begin{array}{l}\text { Rat/ 100, 150, } 175 \mathrm{mg} / \mathrm{kg} \mathrm{bw} / 50 \\
\text { days }\end{array}$ & $\begin{array}{l}\text { Chemically-induced } \\
\text { gastric cancer }\end{array}$ & $\begin{array}{l}\text { Inhibited dose dependently tumor } \\
\text { progression }\end{array}$ \\
\hline $\begin{array}{l}\text { (Festuccia et al., } \\
\text { 2014) }\end{array}$ & $\begin{array}{l}\text { Athymic nude mice/ } 300 \mathrm{mg} / \mathrm{kg} \mathrm{bw} / \\
5 \text { days } / \text { week for } 2 \text { weeks }\end{array}$ & $\begin{array}{l}\text { Xenografted Prostate } \\
\text { Cancer Cells (PC3 and } \\
\text { 22rv1) }\end{array}$ & $\begin{array}{l}\text { Delayed the occurrence of tumor } \\
\text { progression, inhibited of Cell } \\
\text { Invasion, reduced tumor growth }\end{array}$ \\
\hline $\begin{array}{l}\text { (Fujimoto et al., } \\
\text { 2019) }\end{array}$ & $\begin{array}{l}\text { ApcMin/ }+ \text { mice / saffron extract } \\
(0.1 \% \text { and } 0.5 \%) \text { diet for } 4 \text { weeks }\end{array}$ & Intestinal polyps & $\begin{array}{l}\text { Decreased the number of intestinal } \\
\text { polyps in a concentration- } \\
\text { dependent manner. }\end{array}$ \\
\hline $\begin{array}{l}\text { (Nezamdoost et al., } \\
\text { 2020) }\end{array}$ & $\begin{array}{l}\text { Female BALB/c mice/ } 75 \mathrm{mg} / \mathrm{kg} \\
\text { bw/ saffron aqueous extract with } \\
\text { combination of high-intensity interval } \\
\text { training (HIIT) for } 4 \text { weeks }\end{array}$ & $\begin{array}{l}\text { Subcutaneously implanted } \\
4 \mathrm{~T} 1 \text { breast cancer cells }\end{array}$ & Suppressed tumor growth \\
\hline
\end{tabular}

\section{Protective effects of saffron extract}

Few studies examined the harmful toxic effects of saffron on normal cells. Khavari et al. showed that aqueous saffron extract had no cytotoxicity on non-malignant cell (Khavari et al., 2015). Also, D’Alessandro et al. found that saffron extract possesses anticancer activities with no cytotoxic effect on normal and nonmalignant cells (D’Alessandro et al., 2013). Gezici's research revealed that saffron extracts had much more inhibitory properties on cell growth and viability in cancerous cells than in non-malignant cells (Gezici, 2019). Abdullaev's work showed that saffron extract was not toxic up to $1500 \mu \mathrm{g}$ and has not mutagenic effects (Abdullaev et al., 2003).

Saffron has protected endothelial cells from damages such as oxidative stress and apoptosis (Rahiman et al.,
2018) and it has also protected neurons against ROS and glucose toxicity. Saffron was suggested as a drug for diabetic neuropathy treatment (Mousavi et al., 2010).

Pre-treatment with aqueous saffron extract at 20, 40 , and $80 \mathrm{mg} / \mathrm{kg}$ bw in Swiss albino mice significantly decreased the genotoxicity of anti-cancer drugs (Premkumar et al., 2001). Oral administration of $50 \mathrm{mg} /$ $\mathrm{kg}$ bw of the saffron extract significantly diminished the toxicity of cisplatin (CIS) (El Daly, 1998), Another study has reported that a low dose of $2 \mathrm{mg} / \mathrm{kg}$ bw saffron extracts prolonged lifespan in rats treated with CIS and reduced the drug side effects (Nair et al., 1991b). Saffron has good potential to alleviate the toxicity of CIS, including the nephrotoxicity (Wang and DU, 2018). Saffron stigma extract at higher dosage produces less

Table 3. Protective Effects of Saffron Extract from in-vivo Studies

\begin{tabular}{|c|c|c|}
\hline Research & Animal/ Dose/ Time & Results \\
\hline (El Daly, 1998) & Rat/ $50 \mathrm{mg} / \mathrm{kg}$ bw/ 5 days & $\begin{array}{l}\text { Saffron extract }+ \text { cysteine significantly reduced toxic effects of } \\
\text { CIS }\end{array}$ \\
\hline (Nair et al., 1991b) & $\mathrm{Rat} / 2 \mathrm{mg} / \mathrm{kg}$ bw/day / 16 weeks & Reduced the CIS side effects and prolonged lifespan \\
\hline $\begin{array}{l}\text { (Premkumar et al., } \\
\text { 2001) }\end{array}$ & $\begin{array}{l}\text { Mouse/ } 20,40,80 \mathrm{mg} / \mathrm{kg} \mathrm{bw} / 5 \\
\text { days pretreatment }\end{array}$ & $\begin{array}{l}\text { pretreatment with saffron can significantly inhibit the } \\
\text { genotoxicity of CIS, CPH, mitomycin C (MMC) and urethane } \\
\text { (URE) }\end{array}$ \\
\hline (Amin et al., 2011) & $\begin{array}{l}\mathrm{Rat} / 75-300 \mathrm{mg} / \mathrm{kg} \text { bw/day / } 22 \\
\text { weeks }\end{array}$ & $\begin{array}{l}\text { Hepatoprotection from cancer via modulating oxidative damage } \\
\text { and suppressing inflammatory response }\end{array}$ \\
\hline $\begin{array}{l}\text { (Mohajeri et al., } \\
\text { 2011) }\end{array}$ & Rat/ $80 \mathrm{mg} / \mathrm{kg}$ bw/day 30 days & Reduced rifampin-induced hepatotoxicity \\
\hline $\begin{array}{l}\text { (Premkumar et al., } \\
\text { 2006) }\end{array}$ & $\begin{array}{l}\text { Mice/ }(20,40 \text { and } 80 \mathrm{mg} / \mathrm{kg} \text { b.w. }) \\
\text { / for five consecutive days prior to } \\
\text { the administration of anti-tumor } \\
\text { drugs }\end{array}$ & $\begin{array}{l}\text { Pre-treatment with saffron significantly inhibited anti-tumor } \\
\text { drugs induced cellular DNA damage (strand breaks) as revealed } \\
\text { by decreased comet tail length, tail moment and percent DNA in } \\
\text { the tail }\end{array}$ \\
\hline
\end{tabular}


Table 4. Saffron Side-Effects from in-vivo Studies

\begin{tabular}{lccccl}
\hline Research & Research type & Treatment & $\begin{array}{c}\text { Route of } \\
\text { administration }\end{array}$ & Dosage & Toxicity \\
\hline (Abdullaev, 2002) & Animal & Saffron & Oral & $20.7 \mathrm{~g} / \mathrm{kg}$ body wt & Equal to LD50, non-toxic \\
$\begin{array}{l}\text { (Schmidt et al., } \\
2007)\end{array}$ & Animal & Saffron & $\begin{array}{c}\text { Intraperitoneal } \\
\text { Injection }\end{array}$ & $1.2-2.0 \mathrm{~g} / \mathrm{kg} \mathrm{bw}$ & $\begin{array}{l}\text { Nausea, vomiting, diarrhea, } \\
\text { Bleeding }\end{array}$ \\
$\begin{array}{l}\text { (Modaghegh et } \\
\text { al., 2008) }\end{array}$ & Human & Saffron & Oral & $200-400 \mathrm{mg} /$ day & $\begin{array}{l}\text { May change some hematological } \\
\text { and biochemical parameters in } \\
\text { normal ranges }\end{array}$ \\
$\begin{array}{l}\text { (Melnyk et al., } \\
2010)\end{array}$ & Human & Saffron & Oral & $4 \mathrm{~g} / \mathrm{day}$ & Non-toxic \\
\hline
\end{tabular}

cytotoxicity as compared to a standard chemotherapy drug, cyclophosphamide (CPH). On the other hand, methanolic stigma extract has cytoprotection in peripheral blood lymphocytes (Malla et al., 2018). Chahine et al. showed that saffron extracts could have cardio-protective effects against Doxorubicin and/or ischemia/reperfusion injury in pre and post-treatment in rabbit (Chahine and Chahine, 2020).

Another study revealed that a dose of $80 \mathrm{mg} / \mathrm{kg}$ bw alcoholic extract of saffron during 30 days reduced rifampin-induced hepatotoxicity in rats (Mohajeri et al., 2011). Some protective effects of the saffron extract are listed in Table 3.

\section{Side-effects of Saffron}

According to the literature, saffron has very low toxicity effects (Nair et al., 1991a; Nair et al., 1995; Lucas et al., 2001; Abdullaev, 2002; Wichtl, 2004). Contradicting results on the adverse effects of saffron have been reported.

According to a study by Schmidt et al., (2007), consuming more than 10 grams of saffron may stimulate absorption and adverse effects including decreased appetite, insomnia, nausea, vomiting, dizziness, and miscarriage. However, other studies reported no toxicity for the consumption of up to $4 \mathrm{~g} /$ day over several days, even in pregnant women (Melnyk et al., 2010). There are few available reports on allergies to saffron (Lucas et al., 2001).

In-vivo studies in animals found very little or no toxicity of saffron and its components (Nair et al., 1991a; Nair et al., 1995; Karimi et al., 2001). A relative high ID50 equal to $20 \mathrm{~g} / \mathrm{kg}$ bw of saffron (Wichtl, 2004), and a relatively high LD50 of oral consumption of saffron equal to $20.7 \mathrm{~g} / \mathrm{kg}$ bw (Abdullaev, 2002) were found from in-vivo studies; hence researchers consider saffron to be safe for human consumption.

High intake of saffron in the range of $200-400 \mathrm{mg}$ /day alters the biochemical and haematological parameters in the normal range in healthy adults that are not clinically important (Modaghegh et al., 2008). Another study showed that intraperitoneal injection of saffron extract at high doses of $0.35,0.70,1.05 \mathrm{~g} / \mathrm{kg}$ bw to rats caused anaemia and hepato-renal toxicity (Mohajeri et al., 2009). The results of studies on harmful effects and toxicity of saffron in in-vivo studies are presented in Table 4.

\section{Discussion}

The findings of this study demonstrated that saffron extract has the antitumor function, cancer-preventing effects, selective toxicity against cancer cells, and protection of normal cells against the toxicity of anticancer drugs with no cytotoxicity on a normal cell. A number of mechanisms have been proposed for the anticancer activity of saffron and its components (Salomi et al., 1991; Nair et al., 1995; Moradzadeh et al., 2018). Saffron extract exerts its anti-cancer effects via RNA and DNA synthesis inhibition (Abdullaev and Frenkel, 1992; Abdullaev, 1994; Abdullaev, 2002; Tavakkol-Afshari et al., 2008; Patel et al., 2017), apoptosis induction (Tavakkol-Afshari et al., 2008; Samarghandian et al., 2013; Patel et al., 2017; Colapietro et al., 2019), self-renewal genes expression reduction (Akbarpoor et al., 2020), topoisomerase inhibition (Abdullaev, 2002; Lee and Park, 2003; Patel et al., 2017; Wang and DU, 2018), cell proliferation inhibition (Samarghandian et al., 2013; Patel et al., 2017; Colapietro et al., 2019), immune modulation (Khorasanchi et al., 2018), DNA fragmentation (Gezici, 2019), Metalloproteinase and Urokinase modulation (Festuccia et al., 2014), and cell growth reduction (Salomi et al., 1991; Bathaie et al., 2013; Makhlouf et al., 2016). Cancerous cells are more sensitive to the inhibitory effect of saffron on DNA, RNA and protein synthesis than healthy cells (Abdullaev and Frenkel, 1992; Tavakkol-Afshari et al., 2008).

Saffron is involved in tumor prevention and the protection of normal cells through scavenging free radicals (Abdullaev, 2002; Lee and Park, 2003; Patel et al., 2017; Rahiman et al., 2018; Wang and DU, 2018), LDH activity (Gezici, 2019), detoxification (Nair et al., 1991b; Nair et al., 1993; Nair et al., 1994; El Daly, 1998; Premkumar et al., 2001; Premkumar et al., 2003; Mousavi et al., 2010; Mohajeri et al., 2011), inhibition of angiogenesis (Das et al., 2010), inhibition of tumor invasion (Festuccia et al., 2014), tumor formation restriction (Salomi et al., 1991), and lipid peroxidation regulation (Premkumar et al., 2003).

An important point is that the anticancer function of different saffron compounds increases synergistically (Liu, 2004; Tavakkol-Afshari et al., 2008; Makhlouf et al., 2016), so saffron extract might have more anticancer power than its compounds.

Although some studies reported very low toxicity of 
saffron and its components (Nair et al., 1991a; Nair et al., 1995; KARIMI et al., 2001) and considering its safe consumption for human being (Wichtl, 2004), allergy to saffron (Lucas et al., 2001), anaemia, kidney and hepatotoxicity have also been reported in high doses of saffron extract consumption (Mohajeri et al., 2009).

The remarkable point about the anti-cancer function of saffron is that saffron is selectively targeted cancer cells (Kennedy Jr et al., 1986; Loomis and Hayes, 1996). Saffron and its components have low toxicity and can be even considered nontoxic in oral consumption as the actual quantity of saffron used in daily food consumption is much less than the amount that causes complications such as nausea, vomiting, diarrhoea, bleeding, haematological changes, and hepatic and renal toxicity (Escribano et al., 1996; Garc-Olmo et al., 1999; Modaghegh et al., 2008; Mohajeri et al., 2009). Saffron possesses a potent anti-tumor property and has an efficacious and safe treatment (Khorasanchi et al., 2018).

However, despite numerous studies on the anticancer properties of saffron extract, no human clinical trial has been conducted to define the anti-cancer effects of saffron or its components.

However, human clinical trial studies have been conducted on the effects of the saffron extract on other diseases such as allergic asthma (Zilaee et al., 2019), resolution of inflammation in the metabolic syndrome (Kermani et al., 2017; Boskabady et al., 2020), mild/ moderate age-related macular degeneration (Broadhead et al., 2019), diabetic maculopathy (Sepahi et al., 2018), improving sleep quality (Umigai et al., 2018), and depression (Jam et al., 2017; Kashani et al., 2018; Lopresti et al., 2018; Moazen-Zadeh et al., 2018).

It is noted that non-Hodgkin lymphoma (NHL), placed as worldwide the 5 th to 9 th most common cancer (Miranda-Filho et al., 2019) and also incidences of Hodgkin Lymphoma (HL) is increasing (Zhou et al., 2019). However, no study was found about the effect of the saffron extract on these cancers.

In conclusion, this study was made to discover possibility of using saffron as a natural medicine and in particular as anti-cancer drug. Saffron exerts selective toxicity on the cancerous cell by mechanisms including apoptosis, arresting cell cycle progression, tumor cell metabolism modulation, RNA and DNA synthesis inhibition, DNA fragmentation, LDH activity, antioxidant activity, and self-renewal genes expression reduction. In addition, it prevents tumor formation by reacting with and scavenging free radicals.

Also, saffron has anti-cancer and cancer-preventive effects in animal models of cancer, especially in skin, sarcoma, and gastric cancers, which can be related to its antioxidant and apoptotic function in cancer cells. Saffron can also exert antioxidant effects with its vitamin A precursor function. Saffron appears to have protective effects and reduce the toxic effects of anti-cancer drugs.

Saffron has selective toxic and preventive effects on cancer cells but has no side effects on normal cells. Saffron has toxicity effects when used in high dosage, which are far greater than those used in human food culture. Determining the effective dose and effect mechanism of saffron in various animal model cancers requires further studies.

Considering the observed effects of saffron on the removal of cancer cells, saffron extract can be used in the treatment and prevention of cancer after confirmation in human clinical trials.

Generally, due to the high $\mathrm{IC}_{50}$ of saffron extracts in normal cells, their toxicity against non-cancerous cells is low and its use is safe. Besides, studies suggested the effects of saffron on some of the more malignant cancers, including nervous system cancer and common cancers.

According to saffron extract has protective effects against some medications proposing an inventive therapeutic approach to reduce medicinal toxicities and revealing the way for potential clinical applications. In addition, research works for evaluating the effects of saffron extracts of lymphomas are suggested.

The lack of human clinical trials has made it difficult to extend the results of experimental studies on animals to humans and define the best and safest dosage for humans; thus human clinical trials studies in this field are recommended.

\section{References}

Abdullaev F, Frenkel G (1992). The effect of saffron on intracellular DNA, RNA and protein synthesis in malignant and non-malignant human cells. BioFactors (Oxford, England), 4, 43-5.

Abdullaev F, Riveron-Negrete L, Caballero-Ortega H, et al (2003). Use of in vitro assays to assess the potential antigenotoxic and cytotoxic effects of saffron (Crocus sativus L.). Toxicol In Vitro, 17, 731-6.

Abdullaev FI (1994). Inhibitory effect of crocetin on intracellular nucleic acid and protein synthesis in malignant cells. Toxicol lett, 70, 243-51.

Abdullaev FI (2002). Cancer chemopreventive and tumoricidal properties of saffron (Crocus sativus L.). Exp Biol Med, 227, 20-5.

Akbarpoor V, Karimabad MN, Mahmoodi M, et al (2020). The saffron effects on expression pattern of critical self-renewal genes in adenocarcinoma tumor cell line (AGS). Gene Rep, 19, 100629.

Alonso Gl, Salinas Mr, Garijo J, et al (2001). Composition of crocins and picrocrocin from Spanish saffron (Crocus sativus L.). J Food Qual, 24, 219-33.

Amin A, Hamza AA, Bajbouj K, et al (2011). Saffron: a potential candidate for a novel anticancer drug against hepatocellular carcinoma. Hepatology, 54, 857-67.

Azarabadi N, Özdemir F (2018). Determination of crocin content and volatile components in different qualities of iranian saffron. GIDA, 43, 476-89.

Bathaie SZ, Bolhasani A, Hoshyar R, et al (2007). Interaction of saffron carotenoids as anticancer compounds with ctDNA, Oligo (dG. dC) 15, and Oligo (dA. dT) 15. DNA Cell Biol, 26, 533-40.

Bathaie SZ, Miri H, Mohagheghi M-A, et al (2013). Saffron aqueous extract inhibits the chemically-induced gastric cancer progression in the Wistar albino rat. Iran J Basic Med Sci, 16, 27-36.

Bhandari PR (2015). Crocus sativus L.(saffron) for cancer chemoprevention: a mini review. $J$ Tradit Complement Med, 5, 81-7.

Boskabady M-H, Gholamnezhad Z, Khazdair M-R, et al (2020). Antiinflammatory and immunomodulatory effects of saffron 
and its derivatives. In 'Saffron', Eds Elsevier, pp 405-21

Broadhead GK, Grigg JR, McCluskey P, et al (2019). Saffron therapy for the treatment of mild/moderate age-related macular degeneration: a randomised clinical trial. Graefes Arch Clin Exp Ophthalmol, 257, 31-40.

Chahine N, Chahine R (2020). Protecting Mechanisms of Saffron Extract Against Doxorubicin Toxicity in Ischemic Heart. In 'Saffron', Eds Elsevier, pp 141-54.

Colapietro A, Mancini A, D’Alessandro A, et al (2019). Crocetin and crocin from Saffron in cancer chemotherapy and chemoprevention. Anticancer Agents Med Chem, 19, 38-47.

D'Alessandro AM, Mancini A, Lizzi AR, et al (2013). Crocus sativus stigma extract and its major constituent crocin possess significant antiproliferative properties against human prostate cancer. Nutr Cancer, 65, 930-42.

Das I, Das S, Saha T (2010). Saffron suppresses oxidative stress in DMBA-induced skin carcinoma: A histopathological study. Acta Histochem, 112, 317-27.

El Daly ES (1998). Protective effect of cysteine and vitamin E, Crocus sativus and Nigella sativa extracts on cisplatininduced toxicity in rats. $J$ Pharm Belg, 53, 87.

Escribano J, Alonso G-L, Coca-Prados M, et al (1996). Crocin, safranal and picrocrocin from saffron (Crocus sativus L.) inhibit the growth of human cancer cells in vitro. Cancer Lett, 100, 23-30.

Ferlay J, Colombet M, Soerjomataram I, et al (2019). Estimating the global cancer incidence and mortality in 2018: GLOBOCAN sources and methods. Int $J$ Cancer, 144, 1941-53.

Festuccia C, Mancini A, Gravina GL, et al (2014). Antitumor effects of saffron-derived carotenoids in prostate cancer cell models. Bio Med Res Int, 2014, 135048.

Garc-Olmo DC, Riese HH, Escribano J, et al (1999). Effects of long-term treatment of colon adenocarcinoma with crocin, a carotenoid from saffron (Crocus sativus L.): an experimental study in the rat. Nutr Cancer, 35, 120-6.

Gezici S (2019). Comparative anticancer activity analysis of saffron extracts and a principle component, crocetin for prevention and treatment of human malignancies. J Food Sci Technol, 56, 5435-43.

Gezici S, Şekeroğlu N (2019). Current perspectives in the application of medicinal plants against cancer: novel therapeutic agents. Anticancer Agents Med Chem, 19, 101-11.

Gudarzi H, Salimi M, Irian S, et al (2015). Ethanolic extract of Ferula gummosa is cytotoxic against cancer cells by inducing apoptosis and cell cycle arrest. Nat Prod Res, 29, 546-50.

Hain BA, Xu H, Wilcox JR, et al (2019). Chemotherapy-induced loss of bone and muscle mass in a mouse model of breast cancer bone metastases and cachexia. JCSM Rapid Commun Breast, 2, e00075.

Halberstein RA (2005). Medicinal plants: historical and crosscultural usage patterns. Annals of epidemiology, 15, 686-99.

Heitz AE, Baumgartner RN, Baumgartner KB, et al (2018). Healthy lifestyle impact on breast cancer-specific and allcause mortality. Breast Cancer Res Treat, 167, 171-81.

Hoshyar R, Mollaei H (2017). A comprehensive review on anticancer mechanisms of the main carotenoid of saffron, crocin. J Pharm Pharmacol, 69, 1419-27.

Hosseini A, Razavi BM, Hosseinzadeh H (2018). Saffron (Crocus sativus) petal as a new pharmacological target: a review. Iran J Basic Med Sci, 21,1091.

Hosseinzadeh H, Modaghegh MH, Saffari Z (2009). Crocus sativus L.(Saffron) extract and its active constituents (crocin and safranal) on ischemia-reperfusion in rat skeletal muscle. Evid Based Complement Alternat Med, 6, 343-50.

Hosseinzadeh H, Sadeghnia HR, Ghaeni FA, et al (2012). Effects of saffron (Crocus sativus L.) and its active constituent, crocin, on recognition and spatial memory after chronic cerebral hypoperfusion in rats. Phytother Res, 26, 381-6.

Jam IN, Sahebkar AH, Eslami S, et al (2017). The effects of crocin on the symptoms of depression in subjects with metabolic syndrome. Adv Clin Exp Med, 26, 925-30.

Karimi GR, Hosseinzadeh H, Khalegh PP (2001). Study of antidepressant effect of aqueous and ethanolic extract of Crocus sativus in mice. Iran J Basic Med Sci, 4, 11-5.

Kashani L, Esalatmanesh S, Eftekhari F, et al (2018). Efficacy of Crocus sativus (saffron) in treatment of major depressive disorder associated with post-menopausal hot flashes: a double-blind, randomized, placebo-controlled trial. Arch Gynecol Obstet, 297, 717-24.

Kennedy Jr GL, Ferenz RL, Burgess BA (1986). Estimation of acute oral toxicity in rates by determination of the approximate lethal dose rather than the LD50. $J$ Appl Toxicol, 6, 145-8.

Kermani T, Zebarjadi M, Mehrad-Majd H, et al (2017). Anti-inflammatory effect of Crocus sativus on serum cytokine levels in subjects with metabolic syndrome: a randomized, double-blind, placebo-controlled trial. Curr Clin Pharmacol, 12, 122-6.

Khamisipour G, Jadidi-Niaragh F, Jahromi A, et al (2016). Mechanisms of tumor cell resistance to the current targetedtherapy agents. Tumor Biol, 37, 10021-39.

Khanali M, Farahani SS, Shojaei H, et al (2017). Life cycle environmental impacts of saffron production in Iran. Environ Sci Pollut Res Int, 24, 4812-21.

Khavari A, Bolhassani A, Alizadeh F, et al (2015). Chemo-immunotherapy using saffron and its ingredients followed by E7-NT (gp96) DNA vaccine generates different anti-tumor effects against tumors expressing the E7 protein of human papillomavirus. Arch Virol, 160, 499-508.

Khorasanchi Z, Shafiee M, Kermanshahi F, et al (2018). Crocus sativus a natural food coloring and flavoring has potent anti-tumor properties. Phytomedicine, 43, 21-7.

Kokhaei P, Jadidi-Niaragh F, Sotoodeh Jahromi A, et al (2016). Ibrutinib-A double-edge sword in cancer and autoimmune disorders. J Drug Target, 24, 373-85.

Lecomte S, Demay F, Ferrière F, et al (2017). Phytochemicals targeting estrogen receptors: Beneficial rather than adverse effects?. Int J Mol Sci, 18, 1381-9.

Lee BM, Park K-K (2003). Beneficial and adverse effects of chemopreventive agents. Mutat Res, 523, 265-78.

Liu RH (2004). Potential synergy of phytochemicals in cancer prevention: mechanism of action. J Nutr, 134, 3479-85.

Loomis T, Hayes A (1996). Toxicologic testing methods. Loomis's Essentials of Toxicology. Academic Press, Inc., San Diego, CA, pp 205-48.

Lopresti AL, Drummond PD, Inarejos-García AM, et al (2018). Affron ${ }^{\circledR}$, a standardised extract from saffron (Crocus sativus L.) for the treatment of youth anxiety and depressive symptoms: a randomised, double-blind, placebo-controlled study. J Affect Disord, 232, 349-57.

Lou J-S, Yao P, Tsim KW (2018). Cancer treatment by using traditional Chinese medicine: Probing active compounds in anti-multidrug resistance during drug therapy. Curr Med Chem, 25, 5128-41.

Lucas CD, Hallagan JB, Taylor SL (2001). The role of natural color additives in food allergy. Adv Food Nutr Res, 43, 195-216.

Madani AH, Dikshit M, Bhaduri D, et al (2010a). Relationship between selected socio-demographic factors and cancer of oral cavity-a case control study. Cancer Inform, 9, CIN. S4774.

Madani AH, Jahromi AS, Madhurima D, et al (2010b). 
Risk assessment of tobacco types and oral cancer. $\mathrm{Am} \mathrm{J}$ Pharmacol Toxicol, 5, 9-13.

Makhlouf H, Diab-Assaf M, Alghabsha M, et al (2016). In vitro antiproliferative activity of saffron extracts against human acute lymphoblastic T-cell human leukemia. Indian J Tradit Knowled, 15, 16-21.

Malla B, Malla T, Manohar S, et al (2018). Ameliorative potential of crocus sativus with special reference to genotoxicity and cytotoxicity in tumor bearing mice. Res J Life Sci, Bioinform, Pharm Chem Sci, 9, 114-28.

Mani R, Natesan V (2018). Chrysin: Sources, beneficial pharmacological activities, and molecular mechanism of action. Phytochemistry, 145, 187-96.

Melnyk JP, Wang S, Marcone MF (2010). Chemical and biological properties of the world's most expensive spice: Saffron. Food Res Int, 43, 1981-9.

Miranda-Filho A, Piñeros M, Znaor A, et al (2019). Global patterns and trends in the incidence of non-Hodgkin lymphoma. Cancer Causes Control, 30, 489-99.

Moazen-Zadeh E, Abbasi SH, Safi-Aghdam H, et al (2018). Effects of saffron on cognition, anxiety, and depression in patients undergoing coronary artery bypass grafting: a randomized double-blind placebo-controlled trial. J Altern Complement Med, 24, 361-8.

Modaghegh M-H, Shahabian M, Esmaeili H-A, et al (2008). Safety evaluation of saffron (Crocus sativus) tablets in healthy volunteers. Phytomedicine, 15, 1032-7.

Mohajeri D, Doustar Y, Rezaei A, et al (2011). Hepatoprotective effect of ethanolic extract of Crocus sativus L.(Saffron) stigma in comparison with silymarin against rifampin induced hepatotoxicity in rats. Zahedan J Res Med Sci, 12, e94102.

Mohajeri D, Mesgari AM, Delazar A, et al (2009). Histopathological study of subacute toxicity of Crocus sativus L.(Saffron) stigma total extract on liver and kidney tissues in the rat. Pharm Sci, 15, 115-24.

Moradzadeh M, Sadeghnia HR, Tabarraei A, et al (2018). Anti-tumor effects of crocetin and related molecular targets. J Cell Physiol, 233, 2170-82.

Mousavi SH, Tayarani N, Parsaee H (2010). Protective effect of saffron extract and crocin on reactive oxygen speciesmediated high glucose-induced toxicity in PC12 cells. Cell Mol Neurobiol, 30, 185-91.

Nair S, Panikkar K, Parthod R (1993). Protective effects of crocetin on the bladder toxicity induced by cyclophosphamide. Cancer Biother Radiopharm, 8, 339-43.

Nair S, Pannikar B, Panikkar K (1991a). Antitumor activity of saffron (Crocus sativus). Cancer Lett, 57, 109-14.

Nair S, Salomi M, Varghese C, et al (1992). Effect of saffron on thymocyte proliferation, intracellular glutathione levels and its antitumor activity. BioFactors (Oxford, England), 4, 51-4.

Nair S, Varghese CD, Paniker K, et al (1994). Effects of saffron on Vitamin A levels and its Antitumor activity on the growth of solid tumors in mice. Int J Pharmacogn, 32, 105-14.

Nair SC, Kurumboor S, Hasegawa J (1995). Saffron chemoprevention in biology and medicine: a review. Crit Rev Oncol Hematol, 115, , 10, 257-64.

Nair SC, Salomi M, Panikkae B, et al (1991b). Modulatory effects of Crocus sativus and Nigella sativa extracts on cisplatin-induced toxicity in mice. J Ethnopharmacol, 31, 75-83.

Nurgali K, Jagoe RT, Abalo R (2018). Adverse effects of cancer chemotherapy: Anything new to improve tolerance and reduce sequelae?. Front Pharmacol, 9, 245-51.

Organization WH (1978). The promotion and development of traditional medicine: report of a WHO meeting [held in Geneva from 28 November to 2 December 1977].
Patel S, Sarwat M, Khan TH (2017). Mechanism behind the antitumor potential of saffron (Crocus sativus L.): the molecular perspective. Crit Rev Oncol Hematol, 115, 27-35.

Premkumar K, Abraham SK, Santhiya S, et al (2001). Inhibition of genotoxicity by saffron (Crocus sativus L.) in mice. Drug Chem Toxicol, 24, 421-8.

Premkumar K, Abraham SK, Santhiya S, et al (2003). Protective effects of saffron (Crocus sativus Linn.) on genotoxins-induced oxidative stress in Swiss albino mice. Phytother Res, 17, 614-7.

Qi F, Zhao L, Zhou A, et al (2015). The advantages of using traditional Chinese medicine as an adjunctive therapy in the whole course of cancer treatment instead of only terminal stage of cancer. Biosci Trends, 9, 16-34.

Rahiman N, Akaberi M, Sahebkar A, et al (2018). Protective effects of saffron and its active components against oxidative stress and apoptosis in endothelial cells. Microvasc Res, $118,82-9$.

Salomi M, Nair SC, Panikkar K (1991). Inhibitory effects of Nigella sativa and saffron (Crocus sativus) on chemical carcinogenesis in mice. Nutr Cancer, 16, 67-72.

Samarghandian S, Borji A, Farahmand SK, et al (2013). Crocus sativus L.(saffron) stigma aqueous extract induces apoptosis in alveolar human lung cancer cells through caspase-dependent pathways activation. Bio Med Res Int, 2013, 213457.

Sanaei M, Kavoosi F, Arabloo M (2020). Effect of curcumin in comparison with trichostatin a on the reactivation of estrogen receptor alpha gene expression, cell growth inhibition and apoptosis induction in hepatocellular carcinoma hepa 1-6 cell line. Asian Pac J Cancer Prev, 21, 1045-50.

Sanaei M, Kavoosi F, Atashpour S, et al (2017a). Effects of genistein and synergistic action in combination with tamoxifen on the HepG2 human hepatocellular carcinoma cell line. Asian Pac J Cancer Prev, 18, 2381-85.

Sanaei M, Kavoosi F, Salehi H (2017b). Genistein and trichostatin a induction of estrogen receptor alpha gene expression, apoptosis and cell growth inhibition in hepatocellular carcinoma HepG 2 cells. Asian Pac J Cancer Prev, 18, 3445-50.

Sanaei M, Kavoosi F, Valiani A, et al (2018). Effect of genistein on apoptosis and proliferation of hepatocellular Carcinoma Hepa1-6 Cell Line. Int J Prev Med, 9, 12.

Schmidt M, Betti G, Hensel A (2007). Saffron in phytotherapy: pharmacology and clinical uses. Wien Med Wochenschr, 157, 315-24.

Sepahi S, Mohajeri SA, Hosseini SM, et al (2018). Effects of Crocin on diabetic maculopathy: a placebo-controlled randomized clinical trial. Am J Ophthalmol, 190, 89-98.

Small E (2016). 52. Saffron (Crocus sativus)-the eco-friendly spice. Biodiversity, 17, 162-70.

Tarantilis PA, Morjani H, Polissiou M, et al (1994). Inhibition of growth and induction of differentiation of promyelocytic leukemia (HL-60) by carotinoids from. Crocus Sativus, 1913-8.

Tavakkol-Afshari J, Brook A, Mousavi SH (2008). Study of cytotoxic and apoptogenic properties of saffron extract in human cancer cell lines. Food Chem Toxicol, 46, 3443-7.

Umigai N, Takeda R, Mori A(2018). Effect of crocetin on quality of sleep: A randomized, double-blind, placebo-controlled, crossover study. Complement Ther Med, 41, 47-51.

Wang L, DU G-h (2018). Saffron: a potential immunological adjuvant in anti-tumor therapy. Chin J Pharmacol Toxicol, 32, 304-5.

Wichtl M (2004). Herbal drugs and phytopharmaceuticals: a handbook for practice on a scientific basis, Medpharm $\mathrm{GmbH}$ Scientific Publishers. 
Zeinali M, Zirak MR, Rezaee SA, et al (2019). Immunoregulatory and anti-inflammatory properties of Crocus sativus (Saffron) and its main active constituents: A review. Iran J Basic Med Sci, 22, 334.

Zhou L, Deng Y, Li N, et al (2019). Global, regional, and national burden of hodgkin lymphoma from 1990 to 2017: estimates from the 2017 Global Burden of Disease Study. J Hematol Oncol, 12, 107.

Zilaee M, Hosseini SA, Jafarirad S, et al (2019). An evaluation of the effects of saffron supplementation on the asthma clinical symptoms and asthma severity in patients with mild and moderate persistent allergic asthma: a double-blind, randomized placebo-controlled trial. Respir Res, 20, 39.

\section{(ब) $(1)$}

This work is licensed under a Creative Commons AttributionNon Commercial 4.0 International License. 